\title{
RANCANG BANGUN DASHBOARD DALAM MEMONITORING JUMLAH MAHASISWA BARU
}

\author{
Margaretha Yohanna ${ }^{1}$, Yolanda Yulianti Pratiwi Rumapea ${ }^{2}$ \\ 1,2 Universitas Methodist Indonesia \\ Jln Hang Tuah No 8, Medan \\ 1yohanna.na2@gmail.com, ${ }^{2}$ rumapeayolanda@gmail.com
}

\begin{abstract}
Abstrak - Tujuan penting perguruan tinggi dalam membantu pemerintah di bidang Pendidikan yaitu menghasilkan generasi muda yang berkarakter dan berkualitas. Untuk mendukung hal tersebut dibutuhkan suatu sistem yang baik, salah satunya sistem informasi yang dapat memonitoring jumlah mahasiswa baru. Sistem informasi penerimaan mahasiswa baru di salah satu universitas swasta di kota Medan masih bersifat konvensional, dimana pencatatan datadata mahasiswa baru masih berupa teks dan angka. Dengan adanya sistem dashboard yang dikembangkan, memudahkan baik pihak Rektorat maupun Dekanat dalam mengatur strategi dalam mencapai jumlah mahasiswa baru sesuai dengan target yang telah ditetapkan. Selain itu melalui dashboard dihasilkan tampilan yang menarik yaitu dalam bentuk grafik yang relevan sehingga pihak Rektorat dan Dekanat dapat dengan mudah memantau jumlah mahasiswa baru. Penelitian ini menggunakan data mahasiswa baru di salah satu perguruan tinggi swasta di kota Medan. Dari dashboard yang dihasilkan dan dilakukan analisis dapat dilihat jumlah mahasiswa baru yang mendaftar mencapai $83 \%$ dari target yang telah ditetapkan oleh pihak Rektorat dari tahun 2015-2019.
\end{abstract}

Kata Kunci-Dashboard, grafik, mahasiswa baru.

Abstract-An important goal of universities in assisting the government in the field of Education is to produce young people of high quality and character. To support this we need a good system, one of which is an information system that can monitor the number of new students. Acceptance of new student information system at one private university in the city of Medan is still conventional, where recording data freshmen still be text and numbers. With the dashboard system being developed, it makes it easier for both the Rector and the Deans to set a strategy in achieving the number of new students in accordance with the set targets. In addition, through the dashboard, an attractive display is produced, in the form of relevant graphs so that the Rector and the Dean can easily monitor the number of new students. This study uses data of new students in one of the private universities in the city of Medan. From the dashboard generated and analyzed can be seen the number of new students enrolling reaching $83 \%$ of the target set by the Rector of the years 2015-2019.

Keywords—Dashboards, graphics, new students.

\section{PENDAHULUAN}

\section{A. Latar Belakang}

Persaingan di dalam dunia Pendidikan sekarang semakin kompetitif, tidak hanya bagi perguruan tinggi negeri tetapi juga perguruan tinggi swasta. Para mahasiswa yang tidak diterima di perguruan tinggi negeri akan belomba-lomba mencari universitas swasta terbaik dalam melanjutkan pendidikannya. Tujuan perguruan tinggi swasta dalam membantu pemerintah dibidang Pendidikan yaitu menghasilkan generasi muda yang berkarakter dan berkualitas. Untuk mendukung hal tersebut, terutama didalam bidang teknologi informasi, diperlukan suatu sistem pengolahan jumlah mahasiswa baru [1]. Dengan adanya teknologi informasi mampu meningkatkan efektifitas, efisiensi, daya saing dan mendukung kegiatan manajerial organisasi (termasuk dalam bidang Pendidikan).
Salah satu penggunaan teknologi informasi yang sering digunakan di salah satu universitas swasta di Medan yaitu sistem informasi penerimaan mahasiswa baru, di mana sistem tersebut digunakan untuk mencatat jumlah mahasiswa baru yang telah mendaftar. Sistem yang digunakan masih bersifat konvensional, dimana pencatatan data-data mahasiswa baru tersebut masih berupa teks dan angka. Laporan yang dihasilkan juga belum memudahkan pihak Rektorat dan Dekanat dalam mengambil keputusan karena masih berupa data dan belum berupa suatu model informasi. Sistem pelaporan yang kurang baik dan kurang menarik bisa menghambat dalam memonitoring pencapaian target yang diinginkan sehingga tidak bisa mengambil keputusan dengan cepat bila terjadi penurunan jumlah mahasiswa baru.

Untuk menunjang dalam penyediaan sistem informasi yang menarik, data-data yang ada dapat diolah dan direpresentasikan dengan menggunakan sistem dashboard. Dashboard merupakan alat untuk 
menyajikan informasi yang memberikan tampilan antarmuka dalam berbagai bentuk, baik berupa diagram, laporan, indikator visual maupun mekanisme alert yang dipadukan dengan sistem informasi yang dinamis dan relevan [2]. Hasil yang disajikan mudah dipahami dan memberikan gambaran dengan jelas mengenai informasi yang ditampilkan. Dashboard secara umum memiliki tampilan yang sesuai dan mudah dimengerti oleh pihak Rektorat dan Dekanat.

Penelitian dimulai dengan mengumpulkan data mahasiswa baru, seperti data mahasiswa baru, data asal sekolah, data orangtua dan data pendukung lainnya. Tingkat pencapaian kinerja diukur dari KPI (Key performance Indikator) yang disusun oleh pihak Rektorat dan Dekanat. Key Performance Indicator (KPI) merupakan representasi dari sejumlah langkah langkah pengukuran yang berfokus pada aspek - aspek organisasi kinerja yang paling penting untuk mencapai kesuksesan saat ini dan masa depan dari suatu organisasi [3]. Dengan adanya sistem dashboard, pihak Rektorat dan Dekanat dapat dengan mudah memantau semua aspek kinerja penerimaan mahasiswa baru serta dapat dengan cepat mengatur strategi penerimaan mahasiswa baru agar tidak terjadi penurunan jumlah mahasiswa.

\section{B. Data dan Informasi}

Data adalah fakta mengenai objek, orang dan lain sebagainya. Data dapat dinyatakan dengan nilai baik berupa angka-angka, teks atau simbol. Data merupakan unsur terpenting dalam membangun sebuah Database Management System (DBMS). Sedangkan informasi adalah hasil analisis dan sintesis terhadap data, dengan kata lain, informasi merupakan data yang sudah terorganisasikan [4].

\section{Dashboard}

Dashboard merupakan salah satu penyelesaian dalam penyajian dan visualisasi data, dengan menggunakan sistem dashboard, data dan informasi strategis dapat ditampilkan secara online, cepat, dan mudah dipahami oleh pimpinan organisasi [5]. Dashboard merupakan turunan dari sistem informasi eksekutif atau Executive Information System (EIS) dan Decision Support Systems (DSS) dengan sistem data yang lebih kuat dan memanfaatkan Key Performance Indicators (KPI)

Tujuan penggunaan dashboard menurut Eckerson yaitu:

1. Mengkomunikasikan Tujuan dan Strategi

Mengkomunikasikan tujuan dan strategi yang dibuat oleh bagian eksekutif kepada semua pihak yang mempunyai kepentingan, sesuai dengan tingkat dan perannya dalam organisasi tersebut.

2. Memonitor dan Menyesuaikan Pelaksanan Strategi

Memonitoring pelaksanan dari rencana dan strategis yang telah disusun pihak eksekutif untuk mengidentifikasi masalah secara kritis dan membuat strategi untuk mengatasi masalah tersebut.

3. Menyampaikan Wawasan dan Informasi ke Semua Pihak

Menyampaikan informasi kepada semua pihak dengan menggunakan grafik, simbol, bagan dan warna yang memudahkan pengguna dalam memahami informasi secara benar sehingga dapat meningkatkan wawasan pembaca atau pengguna dalam melihat informasi tersebut [6]

Menurut Aanderud dan Homes, beberapa tahapan yang harus dilakukan dalam membangun sebuah dashboard, yaitu:

1. Tentukan hal apa yang ingin diukur oleh pengguna.

2. Membuat layout dan membangun sebuah prototype yang mengacu kepada desain akhir.

3. Mengumpulkan data-data pendukung.

4. Membuat final design dari dashboard.

5. Perhatikan interaksi pengguna dengan dashboard untuk memastikan penerapannya [7].

Beberapa prinsip yang harus diperhatikan dalam membuat dashboard, yakni:

1. Menyediakan informasi berupa Key Performance Indicator (KPI) yang spesifik.

2. Mengintegrasikan beberapa informasi dalam single screen.

3. Bersifat interaktif dan informasi yang saling terintegrasi.

4. Dapat melakukan beberapa hal sekaligus, diantaranya analisis, monitoring, dan prediksi.

5. Bersifat personal, yaitu bergantung kepada kebutuhan pengguna.

6. Memungkinkan kolaborasi dan komunikasi antar section [8].

Terdapat tiga jenis dashboard, yaitu:

1. Tactical Dashboard

Tactical dashboard bertujuan untuk mengukur produktivitas dan efektivitas dalam jangka pendek. Jenis dashboard ini sering digunakan oleh kontributor individu.

2. Operational Dashboard

Operational dashboard bertujuan untuk mengukur fungsi bisnis yang spesifik, padat, atau tingkat unit bisnis dalam jangka pendek. Jenis dashboard ini dapat dikembangkan secara potensial untuk knowledge worker atau local team manager.

3. $\quad$ Strategic Dashboard

Strategic dashboard dibangun untuk tingkatan pengaturan kebijakan dari subuah instansi atau organisasi. Jenis dashboard ini bertujuan untuk menampilkan metrik yang menggambarkan strategi dan tujuan organisasi [9]. 
Beberapa karakteristik dari dashboard yaitu [10]

1. Synergetic.

Tampilan visual yang mudah dipahami oleh pengguna dan bersifat ergonomis.

2. Monitor.

Page | 59 Menampilkan Key Performance Indicator (KPI) yang dibutuhkan untuk keperluan pengambilan keputusan dalam lingkup tertentu, sesuai dengan tujuan pembangunan dashboard tersebut.

3. Accurate.

Informasi yang disajikan harus akurat, dengan tujuan untuk memperoleh kepercayaan dari penggunaanya.

4. Responsive.

Merespon threshold yang telah didenfinisikan, dengan memberikan alert (misalnya bunyi alarm, blinker, atau email) untuk dapat menjadi perhatian terhadap penggunaan hal-hal yang bersifat kritis.

5. Timely.

Menampilkan informasi terkini yang dibutuhkan untuk keperluan pengambilan keputusan.

6. Interactive.

Mampu melakukan drill down dan mendapatkan informasi yang lebih detail, analisis sebab akibat dan lainnya.

7. More data history.

Melihat trend perkembangan KPI, misalnya perbandingan jumlah mahasiswa baru.

8. Personalized.

Informasi yang disajikan harus spesifik untuk setiap jenisnya, sesuai dengan ranah tanggung jawab, hak akses, dan batasan untuk akses data.

9. Analytical.

Menyediakan fasilitas untuk mengerjakan analisis, seperti analisis sebab akibat.

10. Collaborative.

Menyediakan akses pertukaran laporan antar pengguna mengenai hasil pengamatan dashboard masing masing, yaitu sebagai sarana komunikasi dalam menjalankan fungsi kontrol dan manajemen.

11. Trackability.

Memungkinkan setiap pengguna untuk dapat melakukan kustomisasi nilai yang akan diselidiki.

\section{Key Performance Indicator}

Key Performance Indicator (KPI) adalah metrik finansial maupun non finansial yang digunakan untuk membantu organisasi dalam menentukan dan mengukur kemajuan terhadap sasaran organisasi [1] Key Performance Indicator (KPI) merupakan representasi dari sejumlah langkah-langkah pengukuran yang berfokus pada aspek-aspek organisasi kinerja yang paling penting untuk kesuksesan saat ini dan masa depan dari suatu organisasi. KPI umumnya berkaitan dengan strategi organisasi yang diterapkan oleh Teknik, seperti kartu skor berimbang BSC (Balanced Score Card). Kunci utama dalam mengidentifikasi KPI yaitu:

1. Memiliki proses bisnis yang telah ditetapkan sebelumnya.

2. Memiliki tujuan yang jelas dan persyaratan kinerja untuk seluruh proses bisnis.

3. Memiliki pengukuran kuantitatif dan kualitatif dari hasil kerja dengan saran yang ditetapkan.

4. Meneliti penyimpangan dan titik lemah proses untuk mencapai sasaran jangka pendek.

Syarat menyusun KPI (Key Performance Indicator) yang baik haruslah memenuhi kriteria SMART (Specific, Measureable, Achieveable, Relevant, dan Time phased).

1. Specific: kriteria penilaian yang dibuat haruslah secara khusus (spesifik) menilai sebuah aktivitas pekerjaan atau hasil dari suatu pekerjaan.

2. Measureable: semua kriteria yang dinilai ini haruslah bisa diukur.

3. Achieveable: jika menetapkan suatu target untuk dinilai, target ini haruslah sesuatu yang masuk akal untuk dicapai oleh karyawan-karyawan.

4. Relevant: kriteria dan target yang disusun dalam KPI haruslah sesuatu yang relevan atau realistis dengan kondisi dan tujuan perusahaan.

5. Time phased: kriteria penilaian yang dibuat dalam KPI haruslah berpijak pada batasan waktu (rentang waktu) tertentu.

\section{METODE}

\section{A. Tahapan Umum Penelitian}

Ada beberapa tahapan yang dilakukan dalam merancang dashboard untuk memonitoring jumlah mahasiswa baru. Tahapan pertama dimulai dari pengumpulan data mahasiswa baru, setelah semua data terkumpul barulah dilakukan perancangan sistem. Setelah perancangan sistem selesai dilakukan barulah dilakukan tahap implementasi pembuatan dashboard. Setelah implementasi selesai dilakukan maka akan dilakukan proses analisis. Tahap analisis merupakan tahap akhir dalam pembuatan dashboard monitoring mahasiswa baru. Tahapan umum penelitian dapat dilihat pada Gambar 1. 


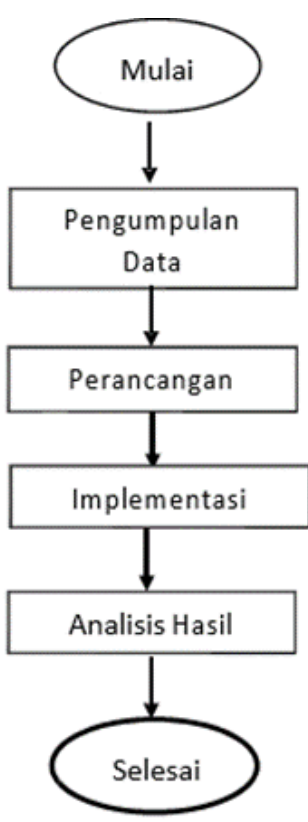

Gbr. 1 Tahapan Umum Penelitian

B. DFD Level 0 / Diagram Konteks

DFD level 0 dirancang untuk menjelaskan hubungan antara sistem dengan dunia luarnya. Perancangan dimulai secara global hingga ke model yang paling detail. DFD level 0 dapat dilihat pada Gambar 2.

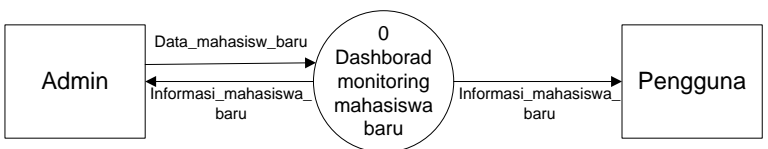

Gbr. 2 DFD Level 0

\section{DFD Level 1}

DFD Level 1 merupakan dekomposisi dari DFD Level 0. Di mana proses yang ada di level 0 dipecah menjadi 2 proses di level 1 . DFD level 1 ini terdiri dari 2 proses yaitu proses login dan proses mahasiswa baru. DFD level 1 dapat dilihat pada Gambar 3.

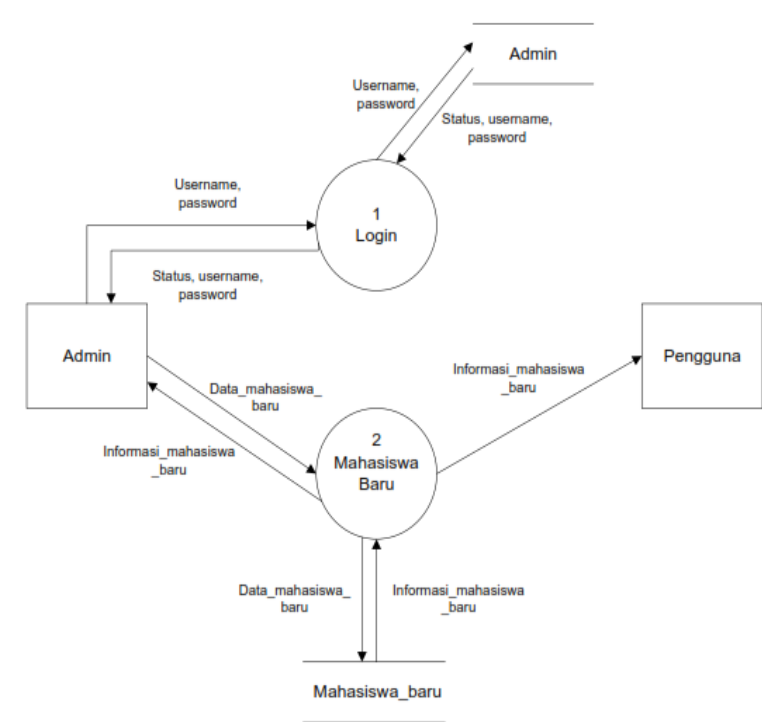

Gbr. 3 DFD Level 1

D. DFD Level 2 Proses 2

DFD Level 2 proses 2 merupakan dekomposisi dari DFD level 1 proses 2 . DFD level 2 proses 2 ini terdiri dari 4 proses yaitu proses lihat mahasiswa baru dimana data akan ditampilkan dalam bentuk dashboard, proses tambah mahasiswa baru, proses ubah mahasiswa baru dan proses hapus mahasiswa baru. DFD level 2 dapat dilihat pada Gambar 4.

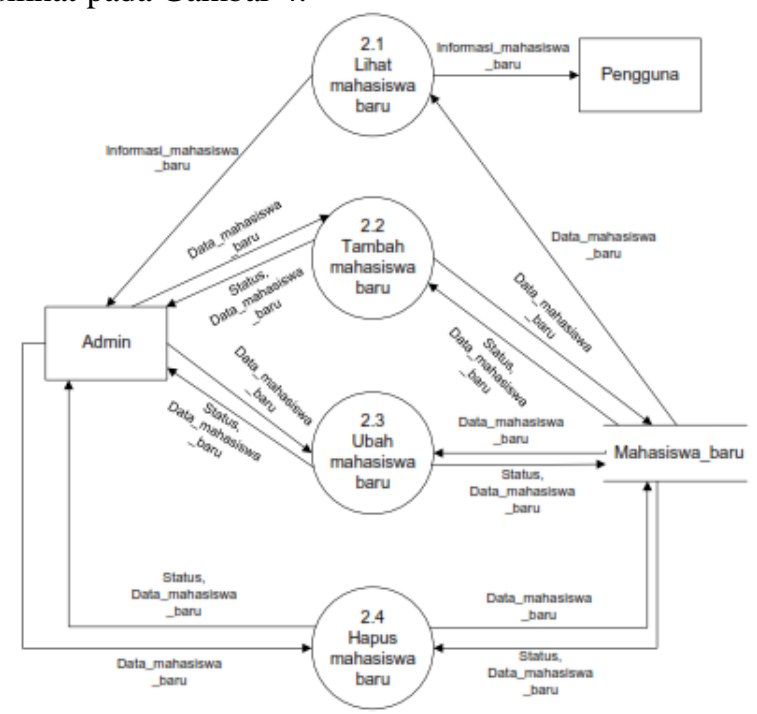

Gbr. 4 DFD Level 2

E. Entity Relational Diagram (ERD)

Gambar 5 merupakan ERD dari perancangan dashboard dalam memonitoring jumlah mahasiswa baru. 
Page $\mid 61$

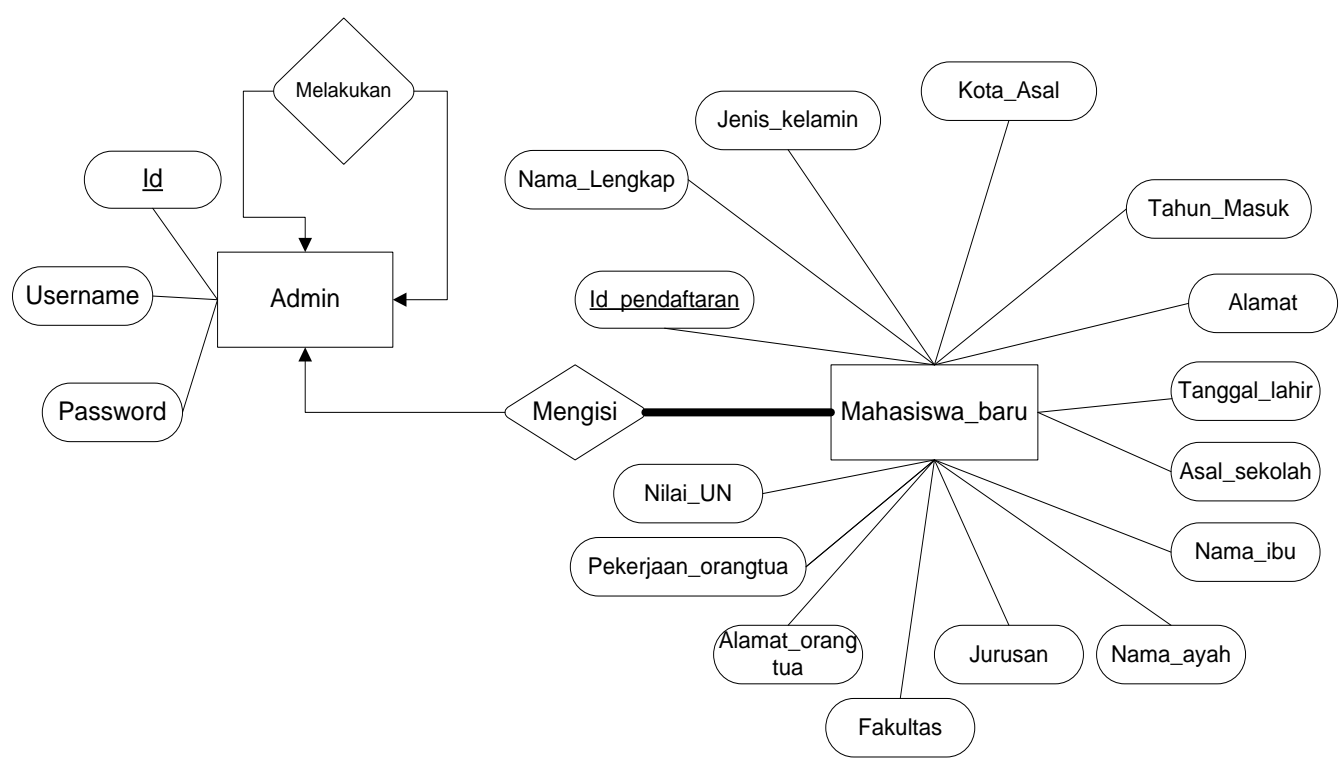

Gbr. 5 ERD

III. HASIL

\section{A. Tampilan Login}

Gambar 6 merupakan tampilan login yang digunakan oleh admin untuk memasukkan data-data mahasiswa baru.

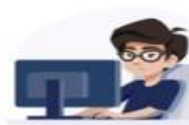

Login Administrator

Username

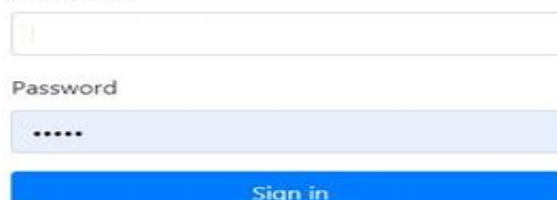

belum punya akun ? sign up here

Gbr. 6 Tampilan Login
B. Tampilan Home Admin

Pada halaman ini tampil data mahasiswa baru secara lengkap, selain itu admin juga bisa menambah, mengubah dan menghapus data mahasiswa baru. Tampilan home admin dapat dilihat pada Gambar 7. 


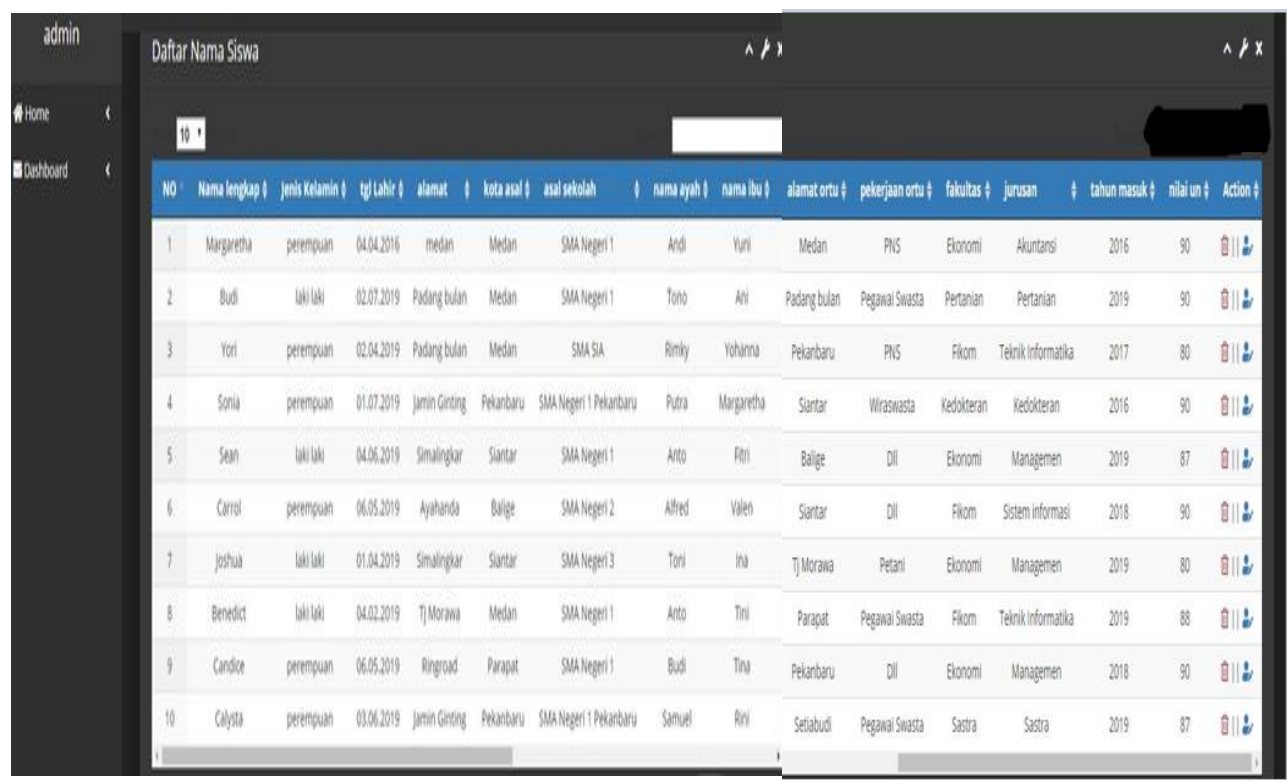

Gbr.7 Tampilan Home Admin

\section{Tampilan Daftar Mahasiswa Baru}

Gambar 8 merupakan tampilan daftar mahasiswa baru, dimana hanya admin yang bisa memasukkan data mahasiswa baru.

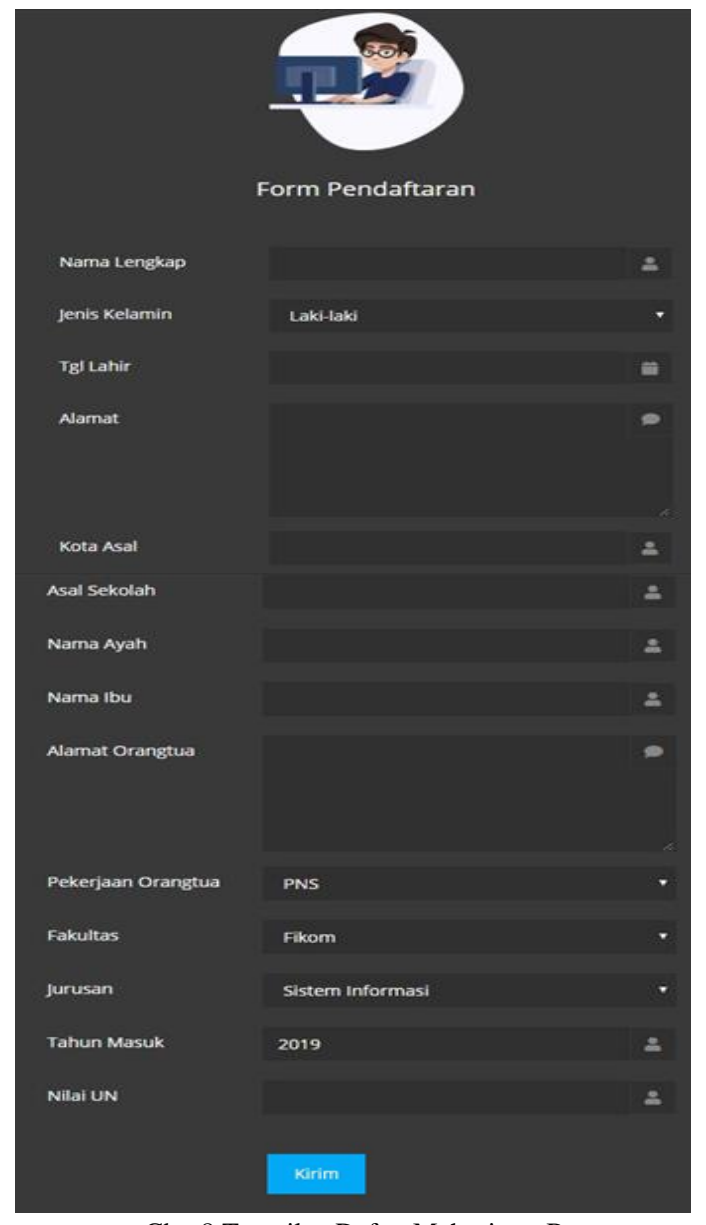

Gbr. 8 Tampilan Daftar Mahasiswa Baru
D. Tampilan Dashboard Berdasarkan Jenis Kelamin

Gambar 9 merupakan dashboard mahasiswa baru berdasarkan jenis kelamin mahasiswa baru dari tahun 2015-2019. Tampilan dashboard baik sebagai admin maupun pengguna lainnya sama.

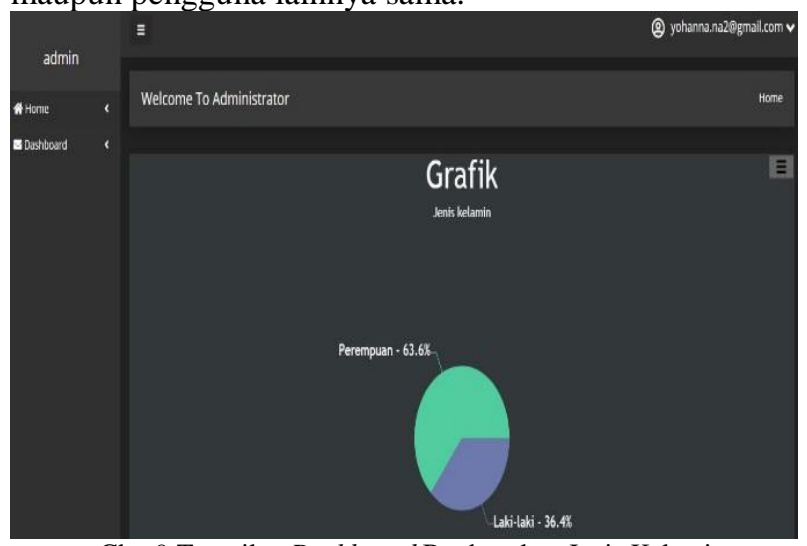

Gbr. 9 Tampilan Dashboard Berdasarkan Jenis Kelamin

\section{E. Tampilan Dashboard Berdasarkan Jurusan}

Gambar 10 merupakan dashboard mahasiswa baru berdasarkan jurusan yang diambil oleh mahasiswa baru dari tahun 2015-2019. Tampilan dashboard baik sebagai admin maupun pengguna lainnya sama. 


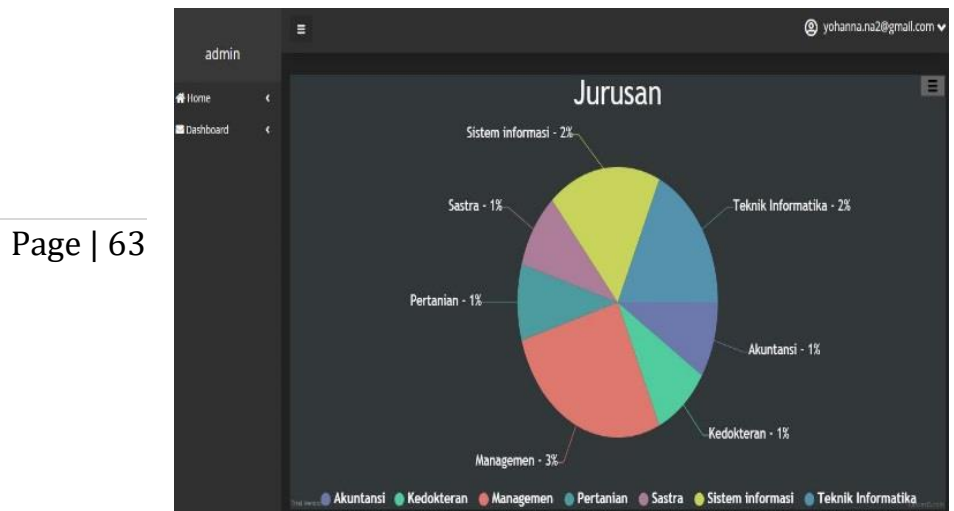

Gbr. 10 Tampilan Dashboard Berdasarkan Jurusan

\section{F. Tampilan Dashboard Berdasarkan Pekerjaan Orangtua}

Gambar 11 merupakan dashboard mahasiswa baru berdasarkan pekerjaan orangtua dari mahasiswa baru dari tahun 2015-2019. Tampilan dashboard baik sebagai admin maupun pengguna lainnya sama.

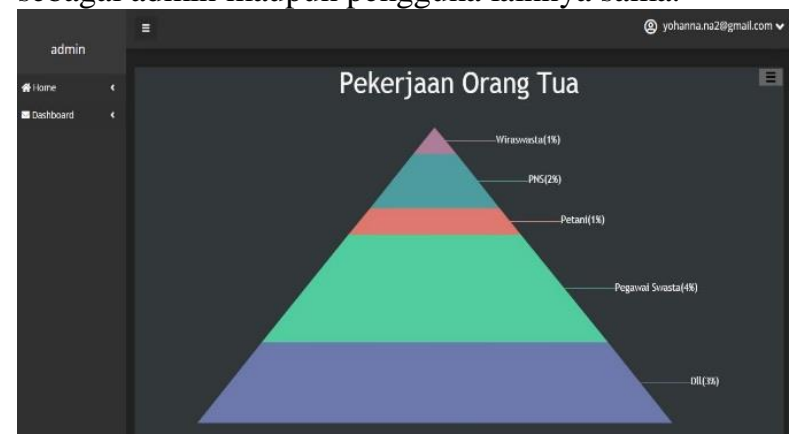

Gbr. 11 Tampilan Dashboard Berdasarkan Pekerjaan Orangtua

\section{PEMBAHASAN}

\section{A. KPI 1: Kinerja Pengukuran KPI Berdasarkan} Jenis Kelamin

Tabel I merupakan kinerja pengukuran KPI berdasarkan Jenis Kelamin. Kolom "target" merupakan target mahasiswa baru berdasarkan jenis kelamin dari tahun 2015-2019. Kolom "realisasi" merupakan data jumlah mahasiswa baru. Kolom "rasio" merupakan persentasi realisasi mahasiswa baru yang mendaftar dibagi dengan target yang ditetapkan oleh pihak Rektorat. Dari tahun 2015-2019 jumlah target mahasiswa baru berdasarkan jenis kelamin yaitu laki-laki sebesar 2.445 orang dan perempuan sebesar 2.445 orang dengan total keseluruhan mahasiswa baru yang ditargetkan sebesar 4.890 orang.

Dari tahun 2015-2019 jumlah mahasiswa baru yang mendaftar dengan jenis kelamin laki-laki sebesar 1.855 orang dengan rasio $76 \%$ dan mahasiswa baru dengan jenis kelamin perempuan yang mendaftar sebesar 2.190 orang dengan rasio 90\%. Dari keseluruhan target yang ditetapkan oleh pihak Rektorat berdasarkan jenis kelamin dan realisasi jumlah mahasiswa baru yang mendaftar didapatkanlah rasio jumlah mahasiswa baru dari tahun 2015-2019 sebesar $83 \%$.
TABEL I

KINERJA PENGUKURAN KPI BERDASARKAN JENIS KELAMIN

\begin{tabular}{llll}
\hline Jenis Kelamin & Target & Realisasi & Rasio \\
\hline Laki-laki & 2.445 & 1.855 & $76 \%$ \\
\hline Perempuan & 2.445 & 2.190 & $90 \%$ \\
\hline Total & $\mathbf{4 . 8 9 0}$ & $\mathbf{4 . 0 4 5}$ & $\mathbf{8 3 \%}$ \\
\hline
\end{tabular}

B. KPI 2: Kinerja Pengukuran KPI Berdasarkan Jurusan

Tabel II merupakan kinerja pengukuran KPI berdasarkan Jurusan. Kolom "target" merupakan target mahasiswa baru berdasarkan jurusan dari tahun 20152019. Kolom "realisasi" merupakan data jumlah mahasiswa baru. Kolom "rasio" merupakan persentasi realisasi mahasiswa baru yang mendaftar dibagi dengan target yang ditetapkan oleh pihak Rektorat. Dari tahun 2015-2019 jumlah target mahasiswa baru berdasarkan jurusan yaitu jurusan Sistem Informasi sebesar 460 orang, jurusan Teknik Informatika sebesar 700 orang, jurusan Manajemen Informatika sebesar 320 orang, jurusan Akuntansi sebesar 1.020 orang, jurusan Manajemen sebesar 820 orang, jurusan Sastra sebesar 410 orang, jurusan Pertanian sebesar 630 orang dan Jurusan Kedokteran sebesar 530 orang dengan total keseluruhan mahasiswa baru yang ditargetkan sebesar 4.890 orang.

Dari tahun 2015-2019 jumlah mahasiswa baru yang mendaftar di jurusan Sistem Informasi sebesar 387 orang dengan rasio $84 \%$. Jumlah mahasiswa baru yang mendaftar di jurusan Teknik Informatika sebesar 621 orang dengan rasio $89 \%$. Jumlah mahasiswa baru yang mendaftar di jurusan Manajemen Informatika sebesar 143 orang dengan rasio 45\%. Jumlah mahasiswa baru yang mendaftar di jurusan Akuntansi sebesar 896 orang dengan rasio 88\%. Jumlah mahasiswa baru yang mendaftar di jurusan Manajemen sebesar 732 orang dengan rasio $89 \%$. Jumlah mahasiswa baru yang mendaftar di jurusan Sastra sebesar 336 orang dengan rasio 82\%. Jumlah mahasiswa baru yang mendaftar di jurusan Pertanian sebesar 520 orang dengan rasio $83 \%$. Jumlah mahasiswa baru yang mendaftar di jurusan Kedokteran sebesar 410 orang dengan rasio 77\%. Dari keseluruhan target yang ditetapkan oleh pihak Rektorat berdasarkan jurusan dan realisasi jumlah mahasiswa baru yang mendaftar didapatkanlah rasio jumlah mahasiswa baru dari tahun 2015-2019 sebesar 83\%.

TABEL II

KINERJA PENGUKURAN KPI BERDASARKAN JURUSAN

\begin{tabular}{cccc}
\hline Jurusan & Target & Realisasi & Rasio \\
\hline Sistem Informasi & 460 & 387 & $84 \%$ \\
\hline Teknik Informatika & 700 & 621 & $89 \%$ \\
\hline $\begin{array}{c}\text { Manajemen } \\
\text { Informatika }\end{array}$ & 320 & 143 & $45 \%$ \\
\hline Akuntansi & 1.020 & 896 & $88 \%$ \\
\hline
\end{tabular}




\begin{tabular}{ccccc} 
& Manajemen & 820 & 732 & $89 \%$ \\
\cline { 2 - 5 } & Sastra & 410 & 336 & $82 \%$ \\
\cline { 2 - 5 } & Pertanian & 630 & 520 & $83 \%$ \\
\cline { 2 - 5 } Page | 64 & Kedokteran & 530 & 410 & $77 \%$ \\
\cline { 2 - 5 } & Total & $\mathbf{4 . 8 9 0}$ & $\mathbf{4 . 0 4 5}$ & $\mathbf{8 3 \%}$ \\
\cline { 3 - 5 } & & &
\end{tabular}

\section{KPI 3: Kinerja Pengukuran KPI Berdasarkan Pekerjaan Orangtua}

Tabel III merupakan kinerja pengukuran KPI berdasarkan Jurusan. Kolom "target" merupakan target mahasiswa baru berdasarkan pekerjaan orangtua dari tahun 2015-2019. Kolom "realisasi" merupakan data jumlah mahasiswa baru. Kolom "rasio" merupakan persentasi realisasi mahasiswa baru yang mendaftar dibagi dengan target yang ditetapkan oleh pihak Rektorat. Dari tahun 2015-2019 jumlah target mahasiswa baru berdasarkan pekerjaan orangtua yaitu PNS sebesar 990 orang, pegawai swasta sebesar 1.360 orang, petani sebesar 680 orang, wiraswasta sebesar 820 orang, dll sebesar 1.040 orang dengan total keseluruhan mahasiswa baru yang ditargetkan sebesar 4.890 orang.

Dari tahun 2015-2019 jumlah mahasiswa baru yang mendaftar dengan pekerjaan orangtua sebagai PNS sebesar 867 orang dengan rasio $88 \%$. Pekerjaan orangtua sebagai pegawai swasta sebesar 1.298 orang dengan rasio $95 \%$. Pekerjaan orangtua sebagai petani sebesar 428 orang dengan rasio 63\%. Pekerjaan orangtua sebagai wiraswasta sebesar 562 orang dengan rasio $69 \%$. Pekerjaan orangtua sebagai dll sebesar 890 orang dengan rasio $86 \%$. Dari keseluruhan target yang ditetapkan oleh pihak Rektorat berdasarkan pekerjaan orangtua dan realisasi jumlah mahasiswa baru yang mendaftar didapatkanlah rasio jumlah mahasiswa baru dari tahun 2015-2019 sebesar 83\%.

TABEL III

KINERJA PENGUKURAN KPI BERDASARKAN PEKERJAAN ORANGTUA

\begin{tabular}{llll}
\hline Pekerjaan Orangtua & Target & Realisasi & Rasio \\
\hline PNS & 990 & 867 & $88 \%$ \\
\hline Pegawai Swasta & 1.360 & 1298 & $95 \%$ \\
\hline Petani & 680 & 428 & $63 \%$ \\
\hline Wiraswasta & 820 & 562 & $69 \%$ \\
\hline Dll & 1.040 & 890 & $86 \%$ \\
\hline Total & $\mathbf{4 . 8 9 0}$ & $\mathbf{4 . 0 4 5}$ & $\mathbf{8 3 \%}$ \\
\hline
\end{tabular}

\section{KESIMPULAN}

Aplikasi dashboard dalam memonitoring jumlah mahasiswa baru ini sangat membantu pihak Rektorat, Dekanat maupun pihak lain yang terlibat proses penerimaan jumlah mahasiswa baru sehingga dapat dengan cepat dilakukan langkah-langkah yang strategis bila terjadi penurunan jumlah mahasiswa baru.
Dari yang dihasilkan dan dilakukan analisis dapat dilihat jumlah mahasiswa baru yang mendaftar mencapai $83 \%$ dari target yang telah ditetapkan oleh pihak rektorat dari tahun 2015-2019.

\section{UCAPAN TERIMA KASIH}

Peneliti mengucapkan terima kasih kepada Direktorat Riset dan Pengabdian Masyarakat, Kementerian Riset, Teknologi, dan Pendidikan Tinggi yang telah mendanai penelitian ini sehingga penelitian ini berjalan dengan baik dan lancar.

\section{DAFTAR PUSTAKA}

[1] Y. Muhamad, F.Ade, H. Uswatun, and A. Siti. 2012. Dashboard Information System Evaluasi Sistem Penerimaan Mahasiswa (Sinema) pada Perguruan Tinggi Raharja. Konferensi Nasional ICT-M Politeknik Telkom (KNIP), ISSN 2302-1896, pp. 276-280.

[2] N.B. I Gst Ngurah, W.I Gst Ngurah. 2017. Visualisasi Dashboard Penerimaan Mahasiswa Baru di STIKOM Bali. Konferensi Nasional Sistem dan Informatika, pp. 401-406.

[3] Parmenter, D. 2007. Key Performance Indicator: Developing, Implementating, and Using Winnning $K P I$, John Wiley and Sons Inc, New Jersey.

[4] A. Haryono. 2012. Pengembangan Sistem Informasi Pengolahan Data Pegawai Sekolah Menengah Pertama Negeri (SMPN) 4 Pacitan. J. Speed - Sentra Penelitian Engineering dan Edukasi, vol. 4, no. 3, pp. $1-9$.

[5] D. Ridho. 2018. Pembangunan Dashboard Lokasi Rawan Tanah Longsor di Indonesia Menggunakan Tableau.2018. Jurnal Teknik Informatika dan Sistem Informasi, vol 4, no 2, ISSN 2443-2229, pp. 254-267.

[6] M. Ropianto. 2017. Pemanfaatan Sistem Dashboard Pada Data Akademik Di Sekolah Tinggi Teknik (STT) Ibnu Sina Batam. Jurnal Teknik Ibnu Sina JTIBSI, vol 2, no 2, pp. 67-71.

[7] A. D. Aipassa, I. Darmawan, and R. Andreswari. 2017. Pembuatan Dashboard Pada Sistem Informasi Pengadaan Barang dan Jasa dengan Metode Extreme Programming (Studi Kasus Logistik Universitas Telkom). Eproceedings of Engineering, paper 4.1, pp. 1005-1011.

[8] D. Nurmalasari, R. T. Wahyuni, and Y. Palapa. 2015. Informational Dashboard untuk Monitoring Sistem Drainase secara Real-Time. JNTETI (Jurnal Nasional Teknik Elektro dan Teknologi Informasi), vol. 4, no. 3.

[9] T. Imam. 2016. Perancangan Data Warehouse Untuk Mndukung Kebutuhan Informasi Penjualan dalam Pengambilan Keputusan (Studi kasus: Sesko Mart). Tugas Akhir Universitas Widyatama.

[10] M. Ropianto. 2017. Pemanfaatan Sistem Dashboard Pada Data Akademik Di Sekolah Tinggi Teknik (STT) Ibnu Sina Batam. Jurnal Teknik Ibnu Sina JTIBSI, vol. 2, no. 2, pp. 67-71. 